\title{
Social media, science communication and the academic super user in the United Kingdom by Yimei Zhu and Kingsley Purdam
}

\begin{abstract}
The Internet and social media tools have created new opportunities for open science including communicating in more interactive ways and sharing research data. Drawing on evidence from interviews and a survey of academics in the United Kingdom our research suggests that most scholars recognised the value and importance of more open science communication and data sharing, but many had concerns about the potential risks. A small group, who can be termed super users, were frequently communicating updates of their ongoing research. It is clear that there are increasing opportunities for more open science and public engagement but challenges remain.
\end{abstract}

\section{Contents}

Introduction Context: Understanding open science, research communication and public engagement Methodology

Findings

Discussion

Conclusions

\section{Introduction}

'Most of my colleagues make me laugh because they are so clueless ... they think their work is over when they hand the final proofs to the publisher.' (Male, Professor, Anthropology)

In the so-called age of data, tensions persist in terms of who has access to academic research and data. Open science is founded on the belief that "scientific knowledge of all kinds should be openly shared as early as is practical in the discovery process" (Nielsen, 2011). The idea of open science can be traced to the early seventeenth century when science was predominantly a more secretive process (David, 2008).

Underlying the push towards more open science is a sense of public duty to inform, share and understand (Levin, et al., 2016). The debates about science communication link directly to discussions about the democratisation of knowledge and challenges posed by competing truth claims. Science communication and open science can bring into question the very ideas of the expert and expertise (Bauman, 1987; Benkler and Nissenbaum, 2006; Giddens, 1991; Habermas, 1996).

The so-called deficit model describes how science communication has often been a one-way process focused on educating the public rather than a more dialogue-based engagement (Davies, 2008; Irwin and Wynne, 1996; Gregory and Miller, 1998; Miller, 2001; Priest, 2001; Sturgis and Allum, 2004; Royal Society, 2012a). There are increasing opportunities for communicating science and public engagement in the research process, which in turn could be the basis for tackling challenging problems.

Traditionally the establishment of knowledge and scientific communication has been through peerreviewed scholarly journals (Lynch, 2009). While such a process has been important in ensuring scientific robustness, subscription-based publishing models and peer-review processes can take considerable time and hinder the dissemination of research to wider audiences (Björk and Solomon, 2013; Chan, et al., 2011). Concerns have been raised about biases in the peer-review and publishing processes (Nature, 2006; Open Science Collaboration, 2015).

Social media tools allow cost-free open access to research in advance of the formal publication of research in traditional, scholarly journals (Manca and Ranieri, 2017). Blogs and social networking sites can include academic blogs and those hosted by a faculty or a research community (Graham and Dutton, 2014; Tatum and Jankowski, 2010) [1]. In the case of Open Notebook Science (for example, 
http://onsnetwork.org), scientist bloggers record day-to-day laboratory work (Research Information Network, 2010). This involves scholarly communication at different stages where scientists invite feedback and participation. Some academic bloggers have reported advantages including networking with peers and potential collaborators, keeping up-to-date with new discoveries within a given field (Kjellberg, 2010). Scholarly publishers are also using blogs to promote papers published in certain journals (Stewart, et al., 2012). Open peer review initiatives have been tested, where a broader audience has been involved in the assessment of manuscripts (Acord and Harley, 2013).

Specialized social networking sites, such as Academia.edu (https://www.academia.edu) and ResearchGate (https://www. researchgate.net), have grown rapidly. Academics share their work on these sites and track publications of other scholars in their disciplines (Thelwall and Kousha, 2014a, 2014b). Some of these online archives provide real-time metrics of access, providing scholars with data on the utility of their own work. While criticism has been levelled at some of these archives for exploiting data (Hall, 2015), their growth suggests a willingness to share their research freely. Nevertheless, some forms of scholarly communication, such as data sharing and open access publishing, present challenges.

We consider the following key research questions in this paper: (i) To what extent do academics support more open science, including sharing research findings and data? (ii) How are scholars using social media to highlight their research work and what concerns do they have? (iii) What are the key factors related to the frequent use of social media to communicate research? (iv) What barriers exist to more open science?

\section{Context: Understanding open science, research communication and public engagement}

The Internet and associated tools for communication offer new opportunities for scientists to engage the public (Veletsianos, 2016). Researchers can inform and engage others in the problem-solving processes of constructing knowledge (Tacke, 2010). These developments link with wider efforts to increase public understanding of science as well as encourage a more open government (Levin, et al., 2016; Royal Society, 2012b; Watermeyer, 2012; Wind-Cowie and Lekhi, 2012) [2]].

There is some debate over a definition of open science. It broadly includes open access to scientific publications, research data, metadata, methods, code, software and findings. Open access (OA) publishing can involve different forms of access but it occur in a timely fashion and include readily available full text of a given paper (Berlin declaration, 2003; Budapest Open Access Initiative, 2002). Open science can include participatory and co-produced research, dynamic communication processes and engagement with ongoing research, also known as Science 2.0 (European Commission, 2014; Grand, et al., 2010; Levin, et al., 2016; Nielsen, 2012; Suber, 2007; Wilbanks, 2006). In co-produced research the public is involved in problem-solving processes and contributes in a variety of ways (Fine and Torre, 2004). Haklay (2013) described extreme citizen science, a ground-up research practice that takes into account local needs and works with broad networks of individuals in knowledge creation. This research in some cases leads to forms of citizen mobilisation (Groulx, et al., 2017; Purdam, 2014).

Scheliga and Friesike (2014) point out that there are a variety of obstacles to more open science practices and communication. Key issues include quality assurance and the role of peer review; protection of intellectual property rights (IPR), including copyright and the commercialisation of research; costs of open access; and parameters encouraging the development of careers of researchers (Peters, 2010; Veletsianos, 2016). There are some open access journals that charge fees to publish papers with unlimited access (Willinsky, 2010). For disadvantaged institutions and non-funded researchers, these fees present financial challenges, stimulating the development of a two-tier information system. Concerns have also been raised about the reliability of peer review in some open access journals. For example, Bohannon (2013) found that a deliberately flawed paper was accepted by 157 open access journals.

Procter, et al. (2010) suggested that that the adoption of Internet tools for scholarly communication has been limited but likely to grow. Quan-Haase, et al. (2015) found that for some academics in the humanities Twitter was seen as a critical tool for communication and information sharing within scholarly networks. Holmberg and Thelwall (2014) and Manca and Ranieri (2017) highlighted differences in the extent and type of social media communication in certain disciplines. Carrigan (2013) found that in the U.K. almost 30 sociology departments had a Twitter presence. Rowlands, et al. (2011) found that many of those who use social media often take advantage of multiple formats, including blogging and social networking. Evidence also suggests that social media tools are increasingly being used to enhance student learning and engagement (Gruzd, et al., 2016). However there are still challenges and limits to the scholarly use of social media (Manca and Ranieri, 2016).

Al-Aufi and Fulton (2015) noted a growing use of social media amongst researchers for collaboration and to highlight new research, but there were still widespread concerns about the protection of intellectual property and a lack of training on the use of these tools. Lupton (2014) and Manca and Ranieri (2016) also identified academic concerns about privacy and the blurring of boundaries between personal and professional lives.

More generally science communication raises questions about how research, which might involve complex methods and technical findings, could be communicated effectively to wider audiences, such as those lacking sufficient background knowledge in a given subject or missing resources to keep pace with evolving research (Hilgartner, 1990; Horst, 2013; Mogendorff, et al., 2012; Priest, 2001). Davies (2008) found that a majority of scientists and engineers view science communication as one-way and negative.

Communication, as an 'educational' one-way transfer of information, has been criticised as failing to take into account the importance and value of interactions between diverse audiences (Myers, 2003). There is a link to broader issues of transparency and accountability and the role that scientists and the public can 
play in knowledge generation, particularly for publicly funded research (Hind, 2010; Huijer, 2003; Nelkin, 1967).

\section{Methodology}

Firstly, we conducted a series of scoping interviews with academics in the U.K. Eight interviews were conducted with researchers using social media for scholarly communication as well as five scholars not using social media. The interviews focused on attitudes towards science communication and the use of social media as well as wider debates about open science. The interviewees were recruited through professional networks.

Secondly, a national online survey was conducted to explore attitudes towards science communication, data sharing and the use of social media in research development and dissemination. The sampling frame of the survey was a population of academics secured from a random sample of $12 \mathrm{U}$.K. Russell Group universities. An invitational e-mail message with a link to an online survey was sent to over 40,000 scholars.

In total 1,829 usable responses were received of which 46 percent were female and 54 percent male. They were from the following four discipline areas: medical and life sciences (35 percent); natural sciences and engineering (23 percent); social sciences (27 percent); and arts and humanities (15 percent). In terms of age: 35 percent of respondents were aged under 35 years old; 26 percent were 3544; 21 percent were 45-54; and 18 percent were 55 and over. In terms of research experience, 25 percent of respondents had 1 to 5 years experience; 22 percent had $6-10$ years experience; 26 percent had 11-20 years experience; and 27 percent had over 21 years experience. In terms of their roles, 20 percent of respondents were researchers in training (including Ph.D. candidates and master's students); 39 percent were lecturers/research fellows or postdoctoral researchers; 16 percent were senior lecturers or senior researchers; and 24 percent were professors or readers.

Descriptive statistical analysis, factor analysis and regression modelling were conducted. Factor analysis allows the identification of underlying attitudes or behaviours by examining associations between responses to multiple survey questions. Logistic regression methods allowed the modelling of binary dependent variables (Sanders and Brynin, 1998) and the identification of key factors associated with the likelihood of being a super user from 11 survey questions. Thematic analysis was used to identify key issues emerging from written comments to open response questions. All the responses were anonymised.

The sample is broadly representative of the U.K. scholarly population in terms of demographics and academic disciplines (Higher Education Statistics Agency, 2015). However there are limitiations to the survey, given its limited response rate. These limitations are considered later in this paper.

\section{Findings}

\section{Attitudes towards open access publishing and data sharing}

Overall there was a positive attitude amongst scholars towards publishing research in open access formats. Academics were asked: 'How important do you think it is, in general, to make research articles freely accessible online to everyone?'. Ninety-three percent $(1,606$ out of 1,722$)$ stated that they felt it was very, or fairly, important to make research articles freely accessible to everyone. We can explore this notion in more detail in written responses. For example, one comment noted that:

'Work is generally publicly funded, so the public should be able to access it! Plus researchers in developing countries may not have the funds to pay subscriptions.' (Female, Research Fellow, Public Health and Primary Care)

In terms of what happens in practice, respondents were asked: 'Have you published an article in a journal that is open access?' Of those who had published research articles, 41 percent $(649$ out of 1,601) stated they had published in an open access journal and a further 31 percent had plans to publish in an open access journal.

At the same time a number of concerns were expressed about publishing in open access journals. The concerns included copyright, quality assurance and the fees that might be charged to authors. One lecturer raised a concern about the potential problems of the author-payment model for open access journals:

'In principle yes, I prefer open access journals, but the system of author payment is very dangerous; it will discourage and possibly exclude young/independent scholars, or those working at impoverished institutions.' (Female, Research Fellow, Public Health and Primary Care)

There were also concerns about quality control and peer review in open access journals.

'I do not believe that open access journals are of as good quality in terms of peer reviewing and therefore do not rate them highly.' (Male, Senior Lecturer, Applied Health Professions, Dentistry, Nursing and Pharmacy) 
The wider issue of open access and questions about the extent to which people without background subject knowledge can understand technical material was also raised.

"While in principle open access is a good idea I believe there are some potential issues/hazards in the way that research is interpreted and used by a non-academic audience.' (Female, Research Fellow, Business and Management Studies)

Another academic commented on possible risks:

'Anyone in a position (with the required expertise) to understand my research would have institutional access to it. Laypersons would not understand the work.' (Male, Reader, Biological Sciences)

We now examine attitudes to making research data available for re-use. Academics were asked: 'How important do you think it is, in general, to make research data available online for reuse?' Again there was a high level of support, with 86 percent $(1,459$ out of 1,695$)$ stating that it was very or fairly important to make research data available online for re-use. As one scholar commented:

'If the research is funded by public funds, then the data should be accessible for the public.' (Female, Lecturer, Civil and Construction Engineering)

Moreover, there was a link made to issues of efficiency and research transparency.

'It should stop duplication of research and transparency ensures honesty and quality.' (Male, Senior Lecturer, Psychology, Psychiatry and Neuroscience)

Another researcher pointed out the significance of access to data, for:

\begin{abstract}
'the validation of research findings by the community; pump-priming ideas from other scientists and giving value for money from tax-funded research.' (Male, Senior Lecturer, Clinical Medicine)
\end{abstract}

In terms of data sharing in practice, respondents were asked: 'Have you deposited your own primary research data in an online repository that can be reused by other researchers?' Not all academics use primary research data; 24 percent of those who had produced data (360 out of 1,481) stated that they had deposited their own research data in an online repository where it could be re-used by others.

A number of concerns were also expressed about open data, including resources needed to create usable data sets.

'Of course it depends on the kind of data. It could require quite a lot of extra work to make the data clear and easy to access without ambiguity.' (Male, Research Assistant, Aeronautical, Mechanical, Chemical and Manufacturing Engineering)

Another academic highlighted risks of misinterpretation:

'The use of any data without data collectors' insight has a great risk for misinterpretation.' (Female, Senior Lecturer, Clinical Medicine)

Concerns were also expressed about copyright, ethics and confidentiality.

'A lot of my primary research data is copyright protected, e.g., photocopies of newspaper articles and government papers so I couldn't make it available this way even if I wanted to.' (Male, Lecturer, Communication, Cultural and Media Studies)

One lecturer in sociology noted:

'I work with qualitative data, where issues of confidentiality and anonymity are paramount ... Placing data in online repositories open for all would feel too risky ... with regards to protecting research participants' anonymity.' (Female, Senior Lecturer, Sociology)

Concerns were also raised about intellectual property and competition with other researchers.

'I am not sure that all data needs to be available to everyone immediately because of issues with competition.' (Female, Lecturer, Biological Sciences)

Highlighting concerns about the protection of research, another scholar remarked:

'I think researchers should freely share research data with those colleagues who email and ask personally. I will share the data and we will produce a paper together. I resent, however, spending the time and effort ... for someone else to swoop in and just use the end product.' (Female, Research Fellow, Sociology) 
Use of social media for highlighting research

The use of three social media tools were considered in the survey: blogs, Twitter and sites such as Facebook and ResearchGate. These social media tools are quite different in the services that they provide. Blogs usually have no word limit and so researchers can write a summary of their published papers. Social networking sites, such as Academia.edu and ResearchGate, allow users to upload entire papers.

A number of participants posted their links in Twitter and Facebook accounts to their blogs to publicise their posts. As such, it was important to capture multiple uses of these tools.

The survey found that the vast majority had never posted updates of ongoing research on blogs ( 84 percent, 1,407 out of 1,668 ); Twitter ( 84 percent, 1,401 out of 1,673 ); or social networking sites ( 81 percent, 1,360 out of 1,671$)$. Overall 70 percent $(1,167$ out of 1,677$)$ had never posted updates of ongoing research on any social media sites.

\begin{tabular}{|c|c|c|c|c|c|c|c|c|c|}
\hline \multirow{2}{*}{$\begin{array}{l}\text { How often do you do any } \\
\text { of the following in your } \\
\text { research work? }\end{array}$} & \multicolumn{2}{|c|}{ Always } & \multicolumn{2}{|c|}{ Often } & \multicolumn{2}{|c|}{ Sometimes } & \multicolumn{2}{|c|}{ Never } & \multirow[t]{2}{*}{ Total } \\
\hline & $N$ & $\%$ & $N$ & $\%$ & $N$ & $\%$ & $N$ & $\%$ & \\
\hline $\begin{array}{l}\text { Publish research updates } \\
\text { on blogs }\end{array}$ & 17 & 1 & 40 & 2 & 204 & 12 & 1,407 & 84 & 1,668 \\
\hline $\begin{array}{l}\text { Publish research updates } \\
\text { on Twitter }\end{array}$ & 25 & 1 & 65 & 4 & 182 & 11 & 1,401 & 84 & 1,673 \\
\hline $\begin{array}{l}\text { Publish research updates } \\
\text { on other social network } \\
\text { sites }\end{array}$ & 10 & 1 & 46 & 3 & 255 & 15 & 1,360 & 81 & 1,671 \\
\hline $\begin{array}{l}\text { Publish research updates } \\
\text { on at least one of the } \\
\text { above }\end{array}$ & 32 & 2 & 107 & 6 & 371 & 22 & 1,167 & 70 & 1,677 \\
\hline
\end{tabular}

However, there were a small number who either 'always' or 'often' ( 8 percent, 139 out of 1,677 ) published updates of ongoing research using at least one of these social media tools. We return to consider this high frequency user group, or 'super users', in more detail below.

We now examine attitudes towards the potential benefits and negative consequences of using social media in their research. As Table 2 highlights, academics were asked to what extent they agreed or disagreed with different statements regarding using social media in their work. The single choice answers for 11 items ranged from 'strongly agree' to 'strongly disagree' on a five-point scale.

Table 2: The potential positive and negative consequences of using social media in research work.

\begin{tabular}{|l|l|l|l|l|l|l|l|l|l|l|l|}
\hline $\begin{array}{l}\text { To what extent } \\
\text { do you agree } \\
\text { or disagree } \\
\text { with the } \\
\text { following } \\
\text { statements? }\end{array}$ & $\begin{array}{c}\text { Strongly } \\
\text { agree }\end{array}$ & Agree & $\begin{array}{c}\text { A } \\
\text { disagree } \\
\text { nor } \\
\text { agree }\end{array}$ & Disagree & $\begin{array}{l}\text { Strongly } \\
\text { disagree }\end{array}$ & Total \\
\hline $\begin{array}{l}\text { Communicating } \\
\text { research on } \\
\text { social media } \\
\text { benefits the } \\
\text { public }\end{array}$ & 152 & 9 & 733 & 45 & 565 & 35 & 152 & 9 & 25 & 2 & 1,627 \\
\hline $\begin{array}{l}\text { Communicating } \\
\text { research on } \\
\text { social media } \\
\text { accelerates } \\
\text { scientific } \\
\text { discovery }\end{array}$ & 83 & 5 & 396 & 24 & 806 & 50 & 294 & 18 & 47 & 3 & 1,626 \\
\hline $\begin{array}{l}\text { Using social } \\
\text { media promotes } \\
\text { my professional } \\
\text { profile }\end{array}$ & 148 & 9 & 575 & 35 & 584 & 36 & 242 & 15 & 76 & 5 & 1,625 \\
\hline $\begin{array}{l}\text { Using social } \\
\text { media helps me } \\
\text { find collaboration } \\
\text { opportunities }\end{array}$ & 118 & 7 & 524 & 32 & 643 & 40 & 273 & 17 & 69 & 4 & 1,627 \\
\hline Using social & 104 & 6 & 387 & 24 & 747 & 46 & 290 & 18 & 89 & 6 & 1,617 \\
\hline
\end{tabular}




\begin{tabular}{|c|c|c|c|c|c|c|c|c|c|c|c|}
\hline $\begin{array}{l}\text { media benefits } \\
\text { my career }\end{array}$ & & & & & & & & & & & \\
\hline $\begin{array}{l}\text { Blogging or } \\
\text { tweeting about } \\
\text { my publication } \\
\text { will increase } \\
\text { citations }\end{array}$ & 65 & 4 & 434 & 27 & 798 & 49 & 273 & 17 & 61 & 4 & 1,631 \\
\hline $\begin{array}{l}\text { Using social } \\
\text { media increases } \\
\text { my chances of } \\
\text { getting funding }\end{array}$ & 43 & 3 & 191 & 12 & 757 & 47 & 499 & 31 & 134 & 8 & 1,624 \\
\hline $\begin{array}{l}\text { Research } \\
\text { published on } \\
\text { social media } \\
\text { cannot be } \\
\text { trusted }\end{array}$ & 282 & 17 & 667 & 41 & 484 & 30 & 165 & 10 & 27 & 2 & 1,625 \\
\hline $\begin{array}{l}\text { Communicating } \\
\text { research on } \\
\text { social media may } \\
\text { result in } \\
\text { plagiarism }\end{array}$ & 92 & 6 & 630 & 39 & 633 & 39 & 242 & 15 & 28 & 2 & 1,625 \\
\hline $\begin{array}{l}\text { Communicating } \\
\text { research on } \\
\text { social media } \\
\text { risks my good } \\
\text { ideas being } \\
\text { stolen }\end{array}$ & 69 & 4 & 423 & 26 & 708 & 44 & 376 & 23 & 49 & 3 & 1,625 \\
\hline
\end{tabular}

In relation to the potential benefits for the public good, over half (54 percent, 885 out of 1,627) agreed that communicating research on social media would benefit the public. Twenty-nine percent (479 out of $1,626)$ agreed that communicating research on social media would accelerate scientific discovery. Fortyfour percent ( 723 out of 1,625 ) agreed that using social media would promote their professional profiles. Thirty-nine percent $(642$ out of 1,627$)$ agreed that using social media would help them find opportunities for collaboration and 30 percent $(491$ out of 1,617$)$ agreed that using social media would benefit their careers. Thirty-one percent $(499$ out of 1,631$)$ agreed that blogging or tweeting about their publications would increase citations. Only 14 percent $(234$ out of 1,624$)$ agreed that using social media increased their chances of securing funding.

In relation to the possible negative consequences of using social media in their research, over half ( 58 percent, 949 out of 1,625$)$ agreed that research published on social media could not be trusted because of concerns about a lack of peer review. Forty-four percent $(722$ out of 1,625$)$ felt that communicating research on social media might result in plagiarism and 30 percent $(492$ out of 1,625$)$ agreed that communicating research on social media could result in the loss of good ideas.

It is important to explore these concerns in more detail in the written responses of scholars. The issues raised included quality assurance, intellectual property rights, lack of time and resources and the prioritising of the peer review process.

'Because social media is non-reviewed, a push towards enhancing this as a means of science communication will hugely increase the amount of poor science on the Internet. There has to be quality control, and selfpublishing via social media has no means of quality control.' (Male, Professor in Biological Science)

Another academic raised concerns over trust, reliability and the lack of time:

'Amongst senior academic medics real collaborative contacts are made during meetings and departmental visits. If your data is not publishable in a peer reviewed journal there is something wrong with your work. Nobody has time for chatting and tweeting, or trusts an unknown virtual colleague or his data. And what would it serve anyway?' (Female, Senior Lecturer, Clinical Medicine)

The issue of the importance of highly regarded publications was also emphasized. One lecturer in business studies explained:

'While some people are quite involved with social media in my circles, I don't think it matters in the absence of producing those elite publications.' (Female, Lecturer, Business and Management Studies)

One scholar pointed to concerns about intellectual property in relation to publishing ongoing research:

'Twitter makes it very easy for people to see someone else's insights and then pass them off as their own, either on Twitter or in their own academic research. How does one prove plagiarism of ideas without making reference to a publication?' (Female, Ph.D. Student, Sociology) 
These views are related to the tension between communicating research on social media and securing more formal academic recognition. We return to this later in this paper.

Comparing across academic disciplines, age, gender and experience

As shown in Table 3 , academics in the social sciences as well as in the arts and humanities were most likely to report research using social media. Scholars in the medical and life sciences and natural sciences and engineering were the least likely to do so. Seventy-seven percent of researchers in the medical and life sciences had never posted research updates using social media. Younger academics and those with little experience were more likely to publish research on blogs, Twitter and social networking sites.

\begin{tabular}{|c|c|c|c|c|c|c|c|c|c|}
\hline \multirow{2}{*}{$\begin{array}{l}\text { Publish ongoing research } \\
\text { updates on blogs, Twitter } \\
\text { and other social network } \\
\text { sites }\end{array}$} & \multicolumn{2}{|c|}{ Always } & \multicolumn{2}{|c|}{ Often } & \multicolumn{2}{|c|}{ Sometimes } & \multicolumn{2}{|c|}{ Never } & \multirow[t]{2}{*}{ Total } \\
\hline & $N$ & $\%$ & $N$ & $\%$ & $N$ & $\%$ & $N$ & $\%$ & \\
\hline \multicolumn{10}{|l|}{ Discipline } \\
\hline Medical \& life sciences & 4 & 1 & 21 & 4 & 109 & 19 & 452 & 77 & 586 \\
\hline $\begin{array}{c}\text { Natural sciences \& } \\
\text { engineering }\end{array}$ & 6 & 2 & 20 & 5 & 76 & 20 & 281 & 73 & 383 \\
\hline Social sciences & 14 & 3 & 41 & 9 & 114 & 26 & 277 & 62 & 446 \\
\hline Arts \& humanities & 7 & 3 & 25 & 10 & 71 & 28 & 153 & 60 & 256 \\
\hline \multicolumn{10}{|l|}{ Gender } \\
\hline Female & 15 & 2 & 54 & 7 & 167 & 22 & 523 & 69 & 759 \\
\hline Male & 17 & 2 & 53 & 6 & 199 & 22 & 635 & 70 & 904 \\
\hline \multicolumn{10}{|l|}{ Age } \\
\hline Under 35 & 13 & 2 & 50 & 9 & 130 & 23 & 364 & 65 & 557 \\
\hline $35-44$ & 36 & 3 & 36 & 8 & 116 & 26 & 274 & 63 & 438 \\
\hline $45-54$ & 6 & 2 & 16 & 4 & 79 & 21 & 272 & 73 & 373 \\
\hline 55 and over & 1 & 0 & 5 & 2 & 42 & 14 & 252 & 84 & 300 \\
\hline \multicolumn{10}{|l|}{ Academic experience } \\
\hline $1-5$ years & 10 & 3 & 27 & 7 & 85 & 22 & 267 & 69 & 389 \\
\hline $6-10$ years & 9 & 2 & 27 & 7 & 99 & 26 & 242 & 64 & 377 \\
\hline $11-20$ years & 9 & 2 & 41 & 9 & 108 & 25 & 278 & 64 & 436 \\
\hline 21 years or more & 3 & 1 & 9 & 2 & 78 & 17 & 370 & 80 & 460 \\
\hline
\end{tabular}

Overall out of 1,677 responses 139 (8 percent) 'always' or 'often' posted research updates on social media. While this is a small group they are clearly highly engaged with social media to highlight their research. We consider these academics as 'super users'.

The comments in the open-ended survey questions pointed out the benefits of using social media tools including raising the profile of their research, building their networks, engaging in dialogue with other researchers and linking with policy-makers as well as practitioners. One scholar stated:

'... and on social media, most of my colleagues make me laugh because they are so clueless ... they think their work is over when they hand the final proofs to the publisher when, in fact, that's when the real work begins: do you think I got those 8,000 citations from being an academic genius? No, from relentless online promotion (though of course you have to have a product of a good-enough quality for promotion to work). And second, clueless about social media: they think it's some dumb thing for their kids. Long may they remain clueless - makes it easier for me to raise my profile compared to them!' (Male, Professor, Anthropology)

Academics also pointed out the importance of their social media activity in terms of building research links, a wider profile and career progression.

'Social media "indirectly" impacts on my promotion and career advancement as this is the main way I heard about funding, conferences and publication opportunities ... A case study wouldn't have happened if I hadn't stumbled across a tweet about it, I got 5k in funding, made a few connections, might even get a cheeky publication out of it.' (Male, Lecturer, Social Science)

One senior scholar stated that he blogged about important breakthroughs to keep stakeholders engaged in a study:

'My research team blogs updates about the study to keep agencies and potential beneficiaries engaged in the study throughout. I blog on my personal blog about ongoing research for the same purpose. The updates 
are usually milestones reached or preliminary observations from the data.' (Male, Reader, Social Work and Social Policy)

Another academic indicated that research was followed by a broader readership, engaging media around the world:

'We've also had journalists pick up on information we've posted.

Someone from the $x x x$ called me after I wrote a blog post on a certain topic, and the $x x x$ a month or so ago. So clearly we have a strong international list of subscribers.' (Male, Professor, Politics)

At the same time some were concerned about publishing updates of ongoing research. As one researcher stated:

'You need to distinguish between communicating published research and communicating research in progress. Huge difference. Communicating completed research is outreach, communicating ongoing research is giving the game away.' (Male, Senior Researcher, Chemistry)

\section{Academic super users}

We conducted logistic regression modelling to identify factors associated with being a super user. The outcome variable indicated whether scholars were super users (coded as 1), defined as having always or often posted ongoing research updates on blogs, Twitter or other social networking sites. Those academics who 'never' or 'sometimes' performed these activities were coded as 0 .

Independent variables included age; gender; academic discipline; digital device access (laptop, smart phone or tablet computer); whether they had social media training; whether they had been encouraged by their institution or by their colleagues; views on the importance of dissemination of research findings to different audiences; and attitudes towards the benefits and risks of using social media for research.

As outlined in the earlier methodology section, factor analysis was conducted to identify the key components of the 11 question items in the survey. Overall 68 percent of the variance in these 11 items was attributable to three latent factors, identified as: (i) social media use benefits the public good; (ii) individual career benefits; and (iii) risks of using social media. Table 4 illustrates logistic regression analysis of the likelihood of being a super user.

\begin{tabular}{|c|c|c|c|c|c|c|c|c|c|c|}
\hline \multicolumn{11}{|c|}{$\begin{array}{l}\text { Table 4: The likelihood of being a super user. } \\
\text { Note: } N=1,366 \text {. Significance level of OR } * p<.05 ; * * p<.01 ; * * * p<.001 \\
\text { The betas (B) are the coefficients for the logistic regression. The odds ratios (OR) are the } \\
\text { exponential of the Bs. If it is greater than } 1 \text { the OR indicates that as the independent } \\
\text { variable increases so does the likelihood of being a super user. The standard errors (SE) } \\
\text { provide information on how accurate the B coefficient is likely to be given the sample size. }\end{array}$} \\
\hline & & \multicolumn{3}{|c|}{ Model 1} & \multicolumn{3}{|c|}{ Model 2} & \multicolumn{3}{|c|}{ Model 3} \\
\hline & & B & \begin{tabular}{|l|} 
S. \\
E.
\end{tabular} & OR & B & $\begin{array}{l}\text { S. } \\
\text { E. }\end{array}$ & OR & B & \begin{tabular}{|l|} 
S. \\
E.
\end{tabular} & OR \\
\hline \multirow{6}{*}{$\begin{array}{l}\text { Demographic } \\
\text { variables }\end{array}$} & $\begin{array}{l}\text { Gender } \\
\text { (reference - } \\
\text { Female) }\end{array}$ & 0.24 & 0.20 & 1.27 & 0.25 & 0.21 & 1.29 & 0.42 & 0.23 & 1.52 \\
\hline & $\begin{array}{l}\text { Discipline } \\
\text { [Sciences (0); } \\
\text { Humanities } \\
(1)]\end{array}$ & $1.00 * * *$ & 0.20 & 2.71 & $0.99 * * *$ & 0.21 & 2.70 & $0.87 * * *$ & 0.23 & 2.39 \\
\hline & $\begin{array}{l}\text { Age (reference } \\
- \text { under } 35 \text { ) }\end{array}$ & & & & & & & & & \\
\hline & $35-44$ & 0.13 & 0.22 & 1.14 & 0.12 & 0.23 & 1.13 & 0.22 & 0.25 & 1.25 \\
\hline & $45-54$ & $-0.83 * *$ & 0.31 & 0.44 & $-0.80 *$ & 0.32 & 0.45 & -0.36 & 0.35 & 0.70 \\
\hline & 55 and over & $-1.80 * * *$ & 0.48 & 0.17 & $-1.63 * * *$ & 0.49 & 0.20 & -0.88 & 0.52 & 0.42 \\
\hline \multirow{3}{*}{$\begin{array}{l}\text { Access to } \\
\text { equipment }\end{array}$} & $\begin{array}{l}\text { Use of laptop } \\
\text { (reference - } \\
\text { no) }\end{array}$ & & & & 0.02 & 0.52 & 1.02 & 0.18 & 0.58 & 1.20 \\
\hline & $\begin{array}{l}\text { Use of smart } \\
\text { phone } \\
\text { (reference - } \\
\text { no) }\end{array}$ & & & & $0.73 *$ & 0.29 & 2.07 & 0.41 & 0.33 & 1.50 \\
\hline & $\begin{array}{l}\text { Use of tablet } \\
\text { (reference - } \\
\text { no) }\end{array}$ & & & & $0.74 * * *$ & 0.22 & 2.09 & $0.87 * * *$ & 0.24 & 2.38 \\
\hline \multirow[t]{2}{*}{ Context } & $\begin{array}{l}\text { Have received } \\
\text { social media } \\
\text { training } \\
\text { (reference - } \\
\text { no) }\end{array}$ & & & & $0.75 * * *$ & 0.26 & 2.11 & 0.45 & 0.29 & 1.56 \\
\hline & $\begin{array}{l}\text { Been } \\
\text { encouraged by }\end{array}$ & & & & 0.15 & 0.23 & 1.17 & -0.05 & 0.25 & 0.95 \\
\hline
\end{tabular}




\begin{tabular}{|c|c|c|c|c|c|c|c|c|c|}
\hline & $\begin{array}{l}\text { institution to } \\
\text { use social } \\
\text { media } \\
\text { (reference - } \\
\text { no) }\end{array}$ & & & & & & & & \\
\hline & $\begin{array}{l}\text { Colleagues } \\
\text { have } \\
\text { recommended } \\
\text { use of social } \\
\text { media } \\
\text { (reference - } \\
\text { no) }\end{array}$ & & & $0.83 * * *$ & 0.23 & 2.30 & $0.49 *$ & 0.25 & 1.64 \\
\hline \multirow{6}{*}{$\begin{array}{l}\text { Attitudes } \\
\text { towards use } \\
\text { of social } \\
\text { media for } \\
\text { dissemination }\end{array}$} & $\begin{array}{l}\text { Importance of } \\
\text { communicating } \\
\text { research to } \\
\text { public } \\
\text { (reference - } \\
\text { not important) }\end{array}$ & & & $0.59 *$ & 0.24 & 1.81 & 0.38 & 0.26 & 1.46 \\
\hline & $\begin{array}{l}\text { Factor } 1- \\
\text { Positive view } \\
\text { that social } \\
\text { media use } \\
\text { benefits public } \\
\text { good and } \\
\text { contributes to } \\
\text { scientific } \\
\text { discovery } \\
\text { (negative to } \\
\text { positive) }\end{array}$ & & & & & & $0.62 * * *$ & 0.12 & 1.87 \\
\hline & $\begin{array}{l}\text { Factor } 2- \\
\text { Positive view } \\
\text { that social } \\
\text { media benefits } \\
\text { own career }\end{array}$ & & & & & & $1.01 * * *$ & 0.14 & 2.76 \\
\hline & $\begin{array}{l}\text { Factor } 3 \text { - Use } \\
\text { of social media } \\
\text { does not pose } \\
\text { risks, for } \\
\text { example, to } \\
\text { the protection } \\
\text { of intellectual } \\
\text { property rights }\end{array}$ & & & & & & $0.47 * * *$ & 0.11 & 1.59 \\
\hline & Constant & -2.72 & 0.07 & -4.73 & 0.63 & 0.01 & -5.15 & 0.72 & 0.01 \\
\hline & $\begin{array}{l}\text { Nagelkerke R } \\
\text { square }\end{array}$ & 0.09 & & 0.20 & & & 0.35 & & \\
\hline
\end{tabular}

Overall being a younger academic, a scholar in the humanities compared to a researcher in medical and life sciences or natural sciences and engineering, having access to a tablet computer or smart phone, having received some training and peer recommendations were all positively associated with the likelihood of being a super user. The importance of peer recommendations suggests a strong social network influence over the likelihood of using social media in research.

Perhaps, not surprisingly, those academics who agreed that communicating research on social media benefits the public were more likely to be super users. Those who agreed that the use of social media for their research benefited their academic careers were also destined to be super users. Those who were more concerned about the potential risks of using social media for research, such as concerns over intellectual property rights, were less interested in sharing their research on social media.

The findings highlight the importance of a range of factors governing the likelihood of a scholar being a super user.

\section{Discussion}

Our findings suggest that while many academics recognise the importance, and for some, the public duty of more open science communication, the use of some of tools is still limited. There were substantial differences in attitudes and behaviour across academic disciplines and also in terms of age and experience. A training and skills gap appears to be part of the problem. The findings highlight the importance of context as well as administrative and peer support and peer pressure influencing the use of Internet-based communication tools, supporting earlier work by Carrigan (2016), Cruz and Jamias (2013) and Kieslinger (2015).

Citation rates are increasingly important to scholars. There is some evidence of increased citations from work that has been highlighted on social media as well as for research published in openly accessable 
journals and repositories (Niyazov, et al., 2016; Shema, et al., 2014). Indeed, evidence suggests that research published in open access formats is increasingly likely to be referenced on public Web sites such as Wikipedia (Duede, 2015). The potential benefits to the public can be significant and also as a result of dissemination to practitioners. Yet at an institutional level, peer reviewed publications remain the key criterion of assessment. Even so, it is likely that the number of academics using social media in their research will continue to increase. Some British scholars cited their numbers of Twitter followers in their 2014 Research Excellence Framework (REF) impact statements (REF, 2014). The REF determines the allocation of much government funding for higher education in the U.K.

We identified a small group who frequently used social media for their research that we termed as super users. This builds on Kieslinger's (2015) notion of the 'heavy user' where the use of social media is integral to professional lives. In our research super users frequently communicated updates of their research using social media. They appeared to be based in the humanities and social sciences and were younger than their colleagues. Their use of social media contributes to the construction of their profiles in addition to sharing information and developing networks.

Many researchers in our survey had concerns about communication and aspects of open science including a lack of clarity regarding formal policies for open science; risks over intellectual property in relation to other researchers and commercial organisations; ethical issues raised by the reuse of data; quality assurance of peer review; and challenges and potential risks of communicating research to audiences without subject-specific and technical expertise. Sharing research ahead of formal publication could put at risk a given researcher's claims over findings as well as academic credit (Robinson-García, et al., 2016). Indeed, the sharing of data could limit a researcher's future use of that data for their own research and as the basis of future grant applications. For some, a lack of time and resources were additional issues. There were also ethical issues related to security and sensitive information (Butler, 2012).

Some academics elect to use social media to promote their own research. Others communicate with a closed community while some practitioners of open science may choose not to use social media directly. In some case, specialized tools may be utilized for sharing data. However it is clear that social media provides new opportunities for more open and two-way science communication. In turn, it can be a valuable part of the research process. Social media can contribute to the development of collaborative problem solving and lead to a more informed public. In this regard, it is notable that Head, et al. (2017) highlighted the popularity of blogs amongst college graduates even if primarily for personal issues. Talbot (2017) noted the growing importance of scholarly blogs contributing to the decision-making processes of policy-makers.

Restrictions on access thanks to pay walls and other barriers pose difficulties for the wider dissemination of research, even when those studies were publicly funded. Research councils in the U.K. require that all publicly funded research data and metadata should be openly available and reusable in a timely manner (Research Councils UK, 2015). Some journal publishers, such as PLOS ONE (2013), require authors to make data, used in published papers, publicly available. However, this initiative has generated considerable debate amongst scholars over intellectual property rights and those resources needed to prepare data and document how it can be used (Yarkoni, 2014). It is notable that the AllTrials campaign (http://www.alltrials.net) has been focused on the registration of clinical trials as well as recording methods and summary results.

Open access publishing in particular can raise some challenges in terms of costs to individual researchers and research institutions. As such, open access publishing may in part be re-positioning the barrier, in some cases, from the reader to the author. In addition, online open access archives have faced challenges. For example, some publishers have forced sites, like Academia.edu (https://www.academia.edu), to remove certain papers because of claims of copyright infringement (Howard, 2013). In some instances, reviewing and analyzing research data can be overwhelming for some journal editors and reviewers (Acord and Harley, 2013). It is clear that peer review is key to scientific research, but there are new and more open ways for communicating research. There needs to be a greater recognition of the value of more accessible communication channels. In the U.K., the Higher Education Funding Council for England (HEFCE) has required that publications must be available in open access repositories to be eligible for future funding (HEFCE, 2015).

The challenges of communicating research directly to wider audiences remain. In our research some researchers were sceptical of more open communication. Research descriptions and findings can contain highly complex concepts and technical language; there are risks in oversimplification.

\section{Limitations}

This study is one of the largest of its kind to date and adds considerably to an existing evidence base, but there are limitations. As outlined earlier, the scoping interviews to develop the survey were based on a purposive sample. The main survey analysis is based on a large number of responses across a number of universities in the U.K., but those scholars who responded may be more likely to be using social media. As such, we need caution in interpreting the results described in this paper. We may be overestimating the level of social media use amongst researchers. Whilst the overall response rate was low, the respondents were broadly representative of the British academic population in terms of key demographics and discipline areas (Higher Education Statistics Agency, 2015).

\section{Conclusions}

There are opportunities for a more creative dialogue-based relationship between scientists and the public, which would help overcome knowledge gaps and transform the deficit model of conducting and communicating science (Godin and Gingras, 2000; Gregory and Miller, 1998; Levin, et al., 2016; Perrault, 
2013; Sturgis and Allum, 2004). As Grand, et al. (2012) argue, practicing science in the open can help build trust and contribute to a more engaged, informed and critical culture.

Multiple formats and channels need to be utilised as part of an integrated communication process. Research findings should be accessible beyond a specific discipline and its network of researchers.

Given changes in academic research funding as well as the evolution of new tools for communication and data sharing, there are clearly opportunities and incentives for more dynamic science communication and public engagement. However, many challenges need to be resolved at a variety of levels. FM

\section{About the authors}

Dr. Yimei Zhu is a lecturer in digital media at the University of Leicester. She has extensive experience using mixed methods and is interested in developing innovative research methods to collect online data. Her research interests include scholarly and science communication, Chinese social media, social capital and online communities. She has published her research in journals such as Scientometrics and Observatorio.

E-mail: yz411 [at] le [dot] ac [dot] uk

Dr. Kingsley Purdam is a senior lecturer in social research methods and statistics at the University of Manchester. He is an expert in rights, equality and labour markets and conducting research with hard to reach groups. He has experience in conducting social research for the Home Office, Department for Communities and Local Government, Department for Work and Pensions and charities including Crisis and The Big Issue. He has also conducted research on vulnerability in the U.K. on behalf of the International Labour Organisation. His research has been cited in the House of Lords and has been featured widely in the media including the BBC. He has published his research in a number of journals including Environment and Planning, Sociology, Current Sociology, Population, Space and Place, European Sociological Review and British Journal of Politics and International Relations.

E-mail: kingsley [dot] purdam [at] manchester [dot] ac [dot] uk

\section{Acknowledgments}

We would like to acknowledge the time and effort of the interviewees and survey respondents in contributing to this research.

\section{Notes}

1. See, for example, www.scienceblogs.com or www.researchblooging.org.

2. See, for example in the U.K., http://data.gov.uk/ and also the Open Data Institute at https://theodi.orq. Also see the International Council for Science, at https://www.icsu.org/current/news/open-data-in-a-biq-data-world-accord-passes-120-endorsements.

\section{References}

S. K. Acord and D. Harley, 2013. "Credit, time, and personality: The human challenges to sharing scholarly work using Web 2.0," New Media \& Society, volume 15, number 3, pp. 379-397. doi: https://doi.org/10.1177/1461444812465140, accessed 18 October 2017.

A. Al-Aufi and C. Fulton, 2015C. "Impact of social networking tools on scholarly communication: A crossinstitutional study," Electronic Library, volume 33, number 2, pp. 224-241. doi: https://doi.org/10.1108/EL-05-2013-0093, accessed 18 August 2017.

Z. Bauman, 1987. Legislators and interpreters: On modernity, post-modernity, and intellectuals. Cambridge: Polity Press.

Y. Benkler and H. Nissenbaum, 2006. "Commons-based peer production and virtue," Journal of Political Philosophy, volume 14, number 4, pp. 394-2419. doi: https://doi.org/10.1111/j.1467-9760.2006.00235.x, accessed 18 October 2017.

Berlin declaration, 2003. "Berlin declaration on open access to knowledge in the sciences and humanities" (22 October), at http://openaccess.mpg.de/Berlin-Declaration, accessed 18 October 2017.

B.-C. Björk and D. Solomon, 2013. "The publishing delay in scholarly peer-reviewed journals," Journal of Informetrics, volume 7, number 4, pp. 914-923.

doi: https://doi.org/10.1016/i.joi.2013.09.001, accessed 18 October 2017.

J. Bohannon, 2013. "Who's afraid of peer review?" Science, 04 Oct: volume 342, number 6154 (4 October), pp. 60-65.

doi: https://doi.org/10.1126/science.342.6154.60, accessed 18 October 2017.

Budapest Open Access Initiative (BOAI), 2002. "Budapest Open Access Initiative," http://www.budapestopenaccessinitiative.org, accessed 18 October 2017. 
D. Butler, 2012. "Avian flu controversy comes to roost at WHO," Nature (17 February), at http://www. nature.com/news/updated-avian-flu-controversy-comes-to-roost-at-who-1.10055, accessed 18 October 2017.

doi: https://doi.org/10.1038/nature.2012.10055, accessed 18 October 2017.

M. Carrigan, 2016. Social media for academics. London: Sage.

M. Carrigan, 2013. "Is social media becoming mainstream within UK sociology?" (11 June), at http://sociologicalimaqination.orq/archives/13285, accessed January 2016.

L. Chan, B. Kirsop and S. Arunachalam, 2011. "Towards open and equitable access to research and knowledge for development," PLOS Medicine, volume 8, number 3, e1001016. doi: https://doi.org/10.1371/journal.pmed.1001016, accessed 18 October 2017.

F. Cruz and S. B. Jamias, 2013. "Scientists' use of social media: The case of researchers at the University of the Philippines Los Baños," First Monday, volume 18, number 4, at http://firstmonday.org/article/view/4296/3650, accessed 18 October 2017. doi: http://dx.doi.org/10.5210/fm.v18i4.4296, accessed 18 October 2017.

S. R. Davies, 2008. "Constructing communication: Talking to scientists about talking to the public," Science Communication, volume 29, number 4, pp. 413-434.

doi: http://dx.doi.org/10.1177/1075547008316222, accessed 18 October 2017.

E. Duede, 2015. "Wikipedia is significantly amplifying the impact of open access publications," LSE Impact Blog (8 September), at http://blogs.Ise.ac.uk/impactofsocialsciences/2015/09/08/wikipedia-amplifyinqimpact-of-open-access/, accessed February 2016.

European Commission, 2014. "Consultation on 'Science 2.0': Science in transition," at https://ec.europa.eu/research/consultations/science-2.0/consultation en.htm, accessed 18 October 2017.

M. Fine and M. E. Torre, 2004. "Re-membering exclusions: Participatory action research in public institutions," Qualitative Research in Psychology, volume 1, number 1, pp. 15-37.

A. Giddens, 1991. Modernity and self-identity: Self and society in the late modern age. Stanford, Calif.: Stanford University Press.

B. Godin and Y. Gingras, 2000. "What is scientific and technological culture and how is it measured? A multidimensional model," Public Understanding of Science, volume 9, number 1, pp. 43-58. doi: http://dx.doi.org/10.1088/0963-6625/9/1/303, accessed 18 October 2017.

M. Graham and W. H. Dutton (editors) (2014. Society and the Internet: How networks of information and communication are changing our lives. Oxford: Oxford University Press.

A. Grand, C. Wilkinson, K. Bultitude and A. F. T. Winfield, 2012. "Open science: A new 'trust technology'?" Science Communication, volume 34, number 5, pp. 679-689. doi: http://dx.doi.org/10.1177/1075547012443021, accessed 18 October 2017.

A. Grand, K. Bultitude, C. Wilkinson and A. F. T. Winfield, 2010. "Muddying the waters or clearing the stream? Open science as a communication medium," Public Communication of Science and Technology; version at http://eprints.uwe.ac.uk/13540/, accessed 18 October 2017.

J. Gregory and S. Miller, 1998. Science in public: Communication, culture, and credibility. New York: Plenum Trade.

M. Groulx, M. C. Brisbois, C. J. Lemieux, A. Winegardner and L. Fishback, 2017. "A role for nature-based citizen science in promoting individual and collective climate change action? A systematic review of learning outcomes," Science Communication, volume 39, number 1, pp. 45-76. doi: http://dx.doi.org/10.1177/1075547016688324, accessed 18 October 2017.

A. Gruzd, C. Haythornthwaite, D. Paulin, S. Gilbert and M. Esteve del Valle, 2016. "Uses and gratifications factors for social media use in teaching: Instructors' perspectives," New Media \& Society. doi: http://dx.doi.org/10.1177/1461444816662933, accessed 18 October 2017.

J. Habermas, 1996. Between facts and norms: Contributions to a discourse theory of law and democracy. Translated by W. Rehg. Cambridge: Polity Press.

M. Haklay, 2013. "Citizen science and volunteered geographic information: Overview and typology of participation," In: D. Sui, S. Elwood and M. Goodchild (editors). Crowdsourcing geographic knowledge: Volunteered geographic information (VGI) in theory and practice. Dordrecht: Springer International, pp. 105-122.

doi: https://doi.org/10.1007/978-94-007-4587-2 7, accessed 18 October 2017.

G. Hall, 2015. "What does Academia_edu's success mean for open access?" LSE Impact Blog (22 October), at http://blogs.Ise.ac.uk/impactofsocialsciences/2015/10/22/does-academia-edu-mean-openaccess-is-becoming-irrelevant/, accessed October 2015.

A.J. Head, M. Van Hoeck and K. and Hostetler, 2017. "Why blogs endure: A study of recent college graduates and motivations for blog readership," First Monday, volume 22, number 10, at http://firstmonday.org/ojs/article/view/8065/6539, accessed 18 October 2017. doi: http://dx.doi.org/10.5210/fm.v22i10.8065, accessed 18 October 2017. 
Higher Education Funding Council for England (HEFCE), 2015. "Open access research," at http://www.hefce.ac.uk/rsrch/oa/, accessed 18 October 2017.

Higher Education Statistics Agency (HESA), 2015. "Staff in higher education," at https://www.hesa.ac.uk/data-and-analysis/publications/staff-2015-16, accessed 18 October 2017.

S. Hilgartner, 1990. "The dominant view of popularization: Conceptual problems, political uses," Social Studies of Science, volume 20, number 3, pp. 519-539.

doi: http://dx.doi.orq/10.1177/030631290020003006, accessed 18 October 2017.

D. Hind, 2010. The return of the public. London: Verso.

K. Holmberg and M. Thelwall, 2014. "Disciplinary differences in Twitter scholarly communication," Scientometrics, volume 101, number 2, pp. 1,027-1,042. doi: https://doi.org/10.1007/s11192-014-1229-3, accessed 18 October 2017.

M. Horst, 2013. "A field of expertise, the organization, or science itself? Scientists' perception of representing research in public communication, Science Communication, volume 35, number 6, pp. 758779.

doi: https://doi.org/10.1177/1075547013487513, accessed 18 October 2017.

J. Howard, 2013. "Posting your latest article? You might have to take it down," Chronicle of Higher Education (6 December), at http://www.chronicle.com/blogs/wiredcampus/posting-your-latest-articleyou-might-have-to-take-it-down/48865, accessed 18 October 2017.

M. Huijer, 2003. "Reconsidering democracy: History of the Human Genome Project," Science Communication, volume 24, number 4, pp. 479-502. doi: https://doi.org/10.1177/1075547003024004004, accessed 18 October 2017.

A. Irwin and B. Wynne (editors), 1996. Misunderstanding science: The public reconstruction of science and technology. Cambridge: Cambridge University Press.

B. Kieslinger, 2015. "Academic peer pressure in social media: Experiences from the heavy, the targeted and the restricted user," First Monday, volume 20, number 6, at http://firstmonday.org/article/view/5854/4580, accessed 18 October 2017. doi: http://dx.doi.org/10.5210/fm.v20i6.5854, accessed 18 October 2017.

S. Kjellberg, 2010. "I am a blogging researcher: Motivations for blogging in a scholarly context" First Monday, volume 15, number 8, at http://firstmonday.orq/article/view/2962/2580, accessed 18 October 2017.

doi: http://dx.doi.org/10.5210/fm.v15i8.2962, accessed 18 October 2017.

N. Levin, S. Leonelli, D. Weckowska, D. Castle and J. Dupré, 2016. "How do scientists define openness? Exploring the relationship between open science policies and research practice," Bulletin of Science, Technology \& Society, volume 36, number 2, pp. 128-141.

doi: http://dx.doi.orq/10.1177/0270467616668760, accessed 18 October 2017.

D. Lupton, 2014. "'Feeling better connected': Academics' use of social media," News \& Media Research Centre, University of Canberra (10 June), at https://www.canberra.edu.au/about-uc/faculties/artsdesign/attachments2/pdf/n-and-mrc/Feelinq-Better-Connected-report-final.pdf, accessed 18 October 2017.

C. Lynch, 2009. "Jim Gray's fourth paradigm and the construction of the scientific record," In: T. Hey, S. Tansley and K. Tolle (editors). The fourth paradigm: Data-intensive scientific discovery. Redmond, Wash.: Microsoft Research, pp. 177-183; version at https://www.cni.org/publications/cliffs-pubs/jim-graysfourth-paradigm-and-the-construction-of-the-scientific-record, accessed 18 October 2017.

S. Manca and M. Ranieri, 2017. "Networked scholarship and motivations for social media use in scholarly communication," International Review of Research in Open and Distributed Learning, volume 18, number 2, at http://www.irrodl.org/index.php/irrodl/article/view/2859/4084, accessed 18 October 2017.

S. Manca and M. Ranieri, 2016. "'Yes for sharing, no for teaching!' Social media in academic practices," Internet and Higher Education, volume 29, pp. 63-74.

doi: https://doi.org/10.1016/i.iheduc.2015.12.004, accessed 18 October 2017.

S. Miller, 2001. "Public understanding of science at the crossroads," Public Understanding of Science, volume 10 , number 1 , pp. 115-120.

doi: https://doi.org/10.3109/a036859, accessed 18 October 2017.

K. Mogendorff, H. te Molder, B. Gremmen and C. van Woerkum, 2012. "'Everyone may think whatever they like, but scientists ...': Or how and to what end plant scientists manage the science-society relationship," Science Communication, volume 34, number 6, pp. 727-751. doi: https://doi.org/10.1177/1075547011433887, accessed 18 October 2017.

G. Myers, 2003. "Discourse studies of scientific popularization: Questioning the boundaries," Discourse Studies, volume 5, number 2, pp. 265-279. doi: https://doi.org/10.1177/1461445603005002006, accessed 18 October 2017.

Nature, 2006. "Can peer review police fraud?" Nature Neuroscience, volume 9, p. 149. doi: https://doi.org/10.1038/nn0206-149, accessed 18 October 2017.

D. Nelkin, 1967. "Scientific knowledge, public policy, and democracy," Science Communication, volume 1, number 1, pp. 106-122. 
doi: https://doi.org/10.1177/107554707900100106, accessed 18 October 2017.

M. Nielsen, 2012. Reinventing discovery: The new era of networked science. Princeton, N.J.: Princeton University Press.

M. Nielsen, 2011. "An informal definition of OpenScience," Open Science Project (28 July), at http://openscience.org/an-informal-definition-of-openscience/, accessed February 2016.

T. Niyazov, C. Vogel, R. Price, B. Lund, D. Judd, A. Akil, M. Mortonson, J. Schwartzman and M. Shron, 2016 "Open access meets discoverability: Citations to articles posted to Academia.edu," PLOS ONE, volume 11 , number 2 , e0148257. doi: https://doi.org/10.1371/journal.pone.0148257, accessed January 2016.

Open Science Collaboration (OSC), 2015. "Estimating the reproducibility of psychological science," Science, volume 349, number 6251 (28 August).

doi: https://doi.org/10.1126/science.aac4716, accessed January 2016.

M. A. Peters, 2010. "Openness, Web 2.0 technology, and open science," Policy Futures in Education, volume 8 , number 5, pp. 567-574.

doi: https://doi.org/10.2304/pfie.2010.8.5.567, accessed 18 October 2017.

PLOS ONE, 2013. "Data availability," at http://journals.plos.org/plosone/s/data-availability, accessed January 2016.

S. T. Perrault, 2013. Communicating popular science: From deficit to democracy. Basingstoke, Hampshire: Palgrave Macmillan.

S. H. Priest, 2001. "Misplaced faith: Communication variables as predictors of encouragement for biotechnology development," Science Communication, volume 23, number 2, pp. 97-110. doi: https://doi.org/10.1177/1075547001023002002, accessed 18 October 2017.

R. Procter, R. Williams, J. Stewart, M. Poschen, H. Snee, A. Voss and M. Asgari-Targhi, 2010. "Adoption and use of Web 2.0 in scholarly communications," Philosophical Transactions of the Royal Society A: Mathematical, Physical and Engineering Sciences, volume 368, number 1926 (13 September), pp. 4,0394,056. doi: https://doi.org/10.1098/rsta.2010.0155, accessed 18 October 2017.

K. Purdam, 2014. "Citizen social science and citizen data? Methodological and ethical challenges for social research," Current Sociology, volume 2, number 3, pp. 374-392. doi: https://doi.org/10.1177/0011392114527997, accessed 18 October 2017.

A. Quan-Haase, K. Martin and L. McCay-Peet, 2015. "Networks of humanities scholars: The informational and social uses and gratifications of Twitter," Big Data \& Society, volume 2, number 1, at http://iournals.sagepub.com/doi/abs/10.1177/2053951715589417, accessed 18 October 2017. doi: https://doi.orq/10.1177/2053951715589417, accessed 18 October 2017.

Research Councils UK (RCUK), 2015. "RCUK common principles on data policy," at http://www.rcuk.ac.uk/research/datapolicy/, accessed January 2016.

Research Excellence Framework (REF), 2014. "REF impact case studies," at http://impact.ref.ac.uk/CaseStudies/, accessed 18 October 2017.

Research Information Network (RIN), 2010. "Open to all: Case studies of openness in research," at http://www.rin.ac.uk/system/files/attachments/NESTA-RIN Open Science V01 0.pdf, accessed February 2016.

N. Robinson-García, E. Jiménez-Contreras and D. Torres-Salinas, 2016. "Analyzing data citation practices using the data citation index," Journal of the Association for Information Science and Technology, volume 67 , number 12 , pp. 2,964-2,975.

doi: https://doi.org/10.1002/asi.23529, accessed 18 October 2017.

I. Rowlands, D. Nicholas, B. Russell, N. Canty and A. Watkinson, 2011. "Social media use in the research workflow," Learned Publishing, volume 24, number 3, pp. 183-195. doi: https://doi.org/10.1087/20110306, accessed 18 October 2017.

Royal Society, 2012a. "Science as an open enterprise" (21 June), at https://royalsociety.org/topicspolicy/projects/science-public-enterprise/report/, accessed 18 October 2017.

Royal Society, 2012b. "Data sharing and mining," at https://royalsociety.orq/iournals/ethicspolicies/data-sharing-mining/, accessed 18 October 2017.

D. Sanders and M. Brynin, 1998. "Ordinary least squares and logistic regression analysis," In: E. Scarbrough and E. Tanenbaum (editors). Research strategies in the social sciences: A guide to new approaches. Oxford: Oxford University Press, Research Strategies in the Social Sciences, pp. 29-53. doi: https://doi.org/10.1093/0198292376.003.0003, accessed 18 October 2017.

K. Scheliga and S. Friesike, 2014. "Putting open science into practice: A social dilemma?" First Monday, volume 19, number 9, at http://firstmonday.org/article/view/5381/4110, accessed January 2016. doi: http://dx.doi.org/10.5210/fm.v19i9.5381, accessed 18 October 2017.

H. Shema, J. Bar-Ilan and M. Thelwall, 2014. "Do blog citations correlate with a higher number of future citations? Research blogs as a potential source for alternative metrics," Journal of the Association for 
Information Science and Technology, volume 65, number 5, pp. 1,018-1,027. doi: http://dx.doi.org/10.1002/asi.23037, accessed 18 October 2017.

J. Stewart, R. Procter, R. Williams and M. Poschen, 2012. "The role of academic publishers in shaping the development of Web 2.0 services for scholarly communication," New Media \& Society, volume 15, number 3, pp. 413-432.

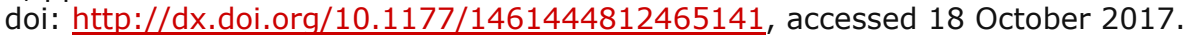

P. Sturgis and N. Allum, 2004. "Science in society: Re-evaluating the deficit model of public attitudes," Public Understanding of Science, volume 13, number 1, pp. 55-74.

doi: http://dx.doi.org/10.1177/0963662504042690, accessed 18 October 2017.

P. Suber, 2007. "More on data sharing in big science and big industry," at http://leqacy.earlham.edu/ peters/fos/2007/03/more-on-data-sharing-in-biq-science-and.html, accessed 18 October 2017.

O. Tacke, 2010. "Open science 2.0: How research and education can benefit from open innovation and Web 2.0," In: T. J. Bastiaens, U. Baumöl and B. J. Krämer (editors). On collective intelligence. Berlin: Springer-Verlag, pp. 37-48.

doi: https://doi.orq/10.1007/978-3-642-14481-3 4, accessed 18 October 2017.

C. Talbot, 2017. "Opinion: how academic blogs can help civil servants create evidence-based policy," Civil Service World (2 October), at https://www.civilserviceworld.com/articles/opinion/opinion-how-academicblogs-can-help-civil-servants-create-evidence-based-policy, accessed 18 October 2017.

C. Tatum and N. W. Jankowski, 2010. "Openness in scholarly communication: Conceptual framework and challenges to innovation" (16 October), at http://digital-scholarship.ehumanities.nl/wp-

content/uploads/Tatum-and-Jankowski-openness-in-scholarly-comm-v202.pdf, accessed 18 October 2017.

M. Thelwall and K. Kousha, 2014a. "Academia.edu: Social network or academic network?" Journal of the Association for Information Science and Technology, volume 65, number 4, pp. 721-731. doi: https://doi.org/10.1002/asi.23038, accessed 18 October 2017.

M. Thelwall and K. Kousha, 2014b. "ResearchGate: Disseminating, communicating, and measuring scholarship?" Journal of the Association for Information Science and Technology, volume 66, number 5, pp. 876-889.

doi: https://doi.org/10.1002/asi.23236, accessed 18 October 2017.

G. Veletsianos, 2016. Social media in academia: Networked scholars. New York: Routledge.

R. Watermeyer, 2012. "Measuring the impact values of public engagement in medical contexts," Science Communication, volume 34, number 6, pp. 752-775. doi: https://doi.org/10.1177/1075547011432804, accessed 18 October 2017.

J. Wilbanks, 2006. "Another reason for opening access to research," British Medical Journal, volume 333, number 7582, pp. 1,306-1,308.

doi: https://doi.org/10.1136/sbmj.39063.730660.F7, accessed 18 October 2017.

M. Wind-Cowie and R. Lekhi, 2012. "The data dividend," Demos (5 March), at https://www.demos.co.uk/project/the-data-dividend/, accessed 18 October 2017.

T. Yarkoni, 2014. "Strong opinions about data sharing mandates - mine included" (12 March), at https://www.talyarkoni.org/blog/2014/03/12/strong-opinions-about-data-sharing-mandates-mineincluded/, accessed 18 October 2017.

\section{Editorial history}

Received 28 April 2017; revised 10 October 2017; accepted 16 October 2017.

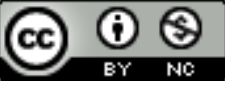

This paper is licensed under a Creative Commons Attribution-NonCommercial 4.0 International License.

Social media, science communication and the academic super user in the United Kingdom by Yimei Zhu and Kingsley Purdam.

First Monday, Volume 22, Number 11 - 6 November 2017

http://journals.uic.edu/ojs/index.php/fm/rt/printerFriendly/7866/6560

doi: $\underline{\text { http://dx.doi.org/10.5210/fm.v22i111.7866 }}$ 